\title{
Induction of DNA Breakdown and Inhibition of Cell Division by Colicin E2. Nature of Some Early Steps in the Process and Properties of the E2-specific Nuclease System
}

\author{
By EVA M. HOLLAND AND I. B. HOLLAND \\ Department of Genetics, University of Leicester, Leicester, LEI 7 RH
}

(Accepted for publication 15 October 1970)

\begin{abstract}
SUMMARY
DNA breakdown was detected 3 to $4 \mathrm{~min}$. after addition of colicin E2 to sensitive cells; inhibition of cell division followed 5 to 10 min. later, but inhibition of DNA synthesis was observed only after several more minutes. Adsorption of E2, which takes place even at $4^{\circ}$, led to the formation of a specific surface complex (I). Complex I did not promote DNA breakdown. We suggest that the transition from this complex to a surface complex (II) which promoted DNA breakdown depended upon several factors which include temperature, concentration of $\mathrm{E}_{2}$, specific membrane proteins and, under certain conditions, high concentrations of extracellular $\mathrm{KH}_{2} \mathrm{PO}_{4}$. The formation of complex II did not depend on concomitant DNA or protein synthesis. The continued promotion of DNA breakdown by complex II and its associated nuclease was blocked by inhibition of energy metabolism. In addition, the removal of $\mathrm{E}_{2}$ from the cell surface by trypsin treatment during the early stages of the process greatly decreased the rate of DNA breakdown. E2-induced DNA breakdown, which appears to commence from a limited number of chromosomal sites, proceeded normally in $\mathrm{UVr}^{-}, \mathrm{RecB}^{-}, \mathrm{RecC}^{-}$, $\mathrm{Hsr}^{-}$, $\mathrm{Hss}^{-}, \mathrm{PolA}^{-}$and in several tsDNA replication mutants.
\end{abstract}

\section{INTRODUCTION}

Colicins appear to act by inducing physicochemical changes in the membrane, which promote specific intracellular changes in the sensitive cell. Evidence has been presented that: (I) Colicin E2 adsorbs to, but does not penetrate, the surface layer of sensitive bacteria (Maeda \& Nomura, I966); (2) E2 does not induce detectable changes in the permeability of the membrane (Nomura, I964); (3) bacteria may be rescued from the lethal effects of $\mathrm{E}_{2}$ for several minutes after adsorption, by digestion of the extracellular colicin with trypsin (Reynolds \& Reeves, 1963; Maeda \& Nomura, I966); (4) mutants which still adsorb $\mathrm{E}_{2}$ but remain insensitive to its presence appear to have altered membranes (Holland et al. 1970; Samson \& Holland, 1970).

To explain the mode of action of colicin, Nomura (1964) proposed that specific transmission systems must exist in the membrane which connect the extracellular colicin to its intracellular target. Such a transmission system or pathway should therefore have specific and identifiable intermediates between the initial colicin-surface complex and the final modified cell component. Since a primary effect of $\mathbf{E} 2$ action is rapid degradation of DNA (Nomura, 1963; Holland, I968), we assumed for the 
purposes of this investigation that a final product in the E2 pathway is a specific DNA-nuclease complex which promotes rapid degradation of DNA. We further assumed that the release of soluble breakdown products of DNA provides a reasonable measure of formation of this complex.

In this study, attempts have been made to establish more clearly the presence of intermediate steps in colicin E2 action and to determine the nature of the processes which affect their formation. The mechanism of DNA breakdown itself appears to proceed via a specific mechanism unrelated to degradative systems involved in known repair or recombination processes.

\section{METHODS}

Strains. Salmonella typhimurium LT 2 strain 906, a colicinogenic strain carrying the $\mathrm{E}_{2}$ (P9) factor, was the source of colicin E2 (Holland, 1968). Escherichia coli $\mathrm{K} 12$ laboratory strain 206 (Hfr $t h y^{-} h i s^{-} \lambda^{-}$) was used as the colicin-sensitive strain. The bacteria were normally grown in Difco nutrient broth supplemented with appropriate amounts of thymine.

Colicin E2. Colicin was used as a crude sterile lysate prepared from a mitomycin C induced culture of strain 906 as described previously (Hill \& Holland, 1967). This material contained no antibacterial activity in addition to E2 (Hill \& Holland, 1967) and behaved in all respects like highly purified preparations of E2 (Holland, I968). For the assay of colicin, serial dilutions of the E 2 preparations were spotted on nutrient broth agar plates previously seeded with strain 206 . After $14 \mathrm{~h}$. at $37^{\circ}$ the highest dilution giving the minimal inhibition of growth was determined and the reciprocal of this dilution taken as the colicin titre. Preparations usually contained $2 \times 10^{5}$ arbitrary units of colicin $\mathrm{E} 2 / \mathrm{ml}$. and were stable for several months at $4^{\circ}$. Concentrations of 0.2 to 0.4 units of $\mathrm{E}_{2} / \mathrm{ml} . / 10^{8}$ bacteria normally killed $50 \%$ at $37^{\circ}$.

Bacterial counts. For total bacterial counts, $0.05 \mathrm{ml}$. culture samples were diluted into non-pyrogenic N-saline (Polyfusor, Boots Pure Drug Co. Ltd, Nottingham) and counted in duplicate in a model $\mathrm{F}$ Coulter counter at densities around $2 \times 10^{4}$ bacteria $/ \mathrm{ml}$.

Determination of DNA breakdown in treated cultures. Strain 206 was aerated in nutrient broth $+2.5 \mu \mathrm{g}$. thymine $/ \mathrm{ml}$., until it reached $5 \times 10^{7}$ bacteria $/ \mathrm{ml}$. The culture was diluted tenfold into the same medium containing $40 \mu \mathrm{Ci}$ methyl- $\left[{ }^{3} \mathrm{H}\right]$ thymine $(2 \mathrm{I} \cdot 8 \mathrm{Ci} / \mathrm{mmole}) / \mathrm{ml}$; incubation was continued for four to five generations to about $2 \times 10^{8}$ bacteria $/ \mathrm{ml}$. The culture was washed twice in nutrient broth +25 or $100 \mu \mathrm{g}$. cold thymine $/ \mathrm{ml}$. and finally suspended in this medium at about $2 \times 10^{7}$ bacteria $/ \mathrm{ml}$. The labelled culture was then incubated at $37^{\circ}$ for $10 \mathrm{~min}$., colicin E2 was added and samples $(0.2 \mathrm{ml}$.) were removed at intervals, mixed with $0.2 \mathrm{ml}$. ice-cold $10 \%$ trichloroacetic acid. After standing $60 \mathrm{~min}$. on ice, the samples were analysed for cold and hot acid-soluble radioactivity as described by Howard-Flanders \& Theriot (1966). Radioactive samples were counted with a Packard Tri-Carb scintillation counter.

Measurement of DNA synthesis. Incorporation of $\left[{ }^{3} \mathrm{H}\right]$ thymine into acid-precipitable material was used as a measure of DNA synthesis in treated cultures as described previously (Holland, I968).

Materials. Mitomycin C, trypsin (type III, twice crystallized) and trypsin inhibitor (Soybean, type I-S, twice crystallized) were obtained from the Sigma Chemical Company. Nalidixic acid was a gift from Bayer Products, Surbiton-upon-Thames, Surrey. 


\section{RESULTS}

\section{Kinetics of DNA breakdown and inhibition of cell division induced by colicin E2}

Previous studies indicated that colicin $\mathrm{E} 2$ causes inhibition of cell division in addition to induction of rapid DNA breakdown (Holland, I968). To determine which was the primary effect, the kinetics of the appearance of these two consequences of colicin action were measured in cultures of Escherichia coli strain 206 prelabelled with $\left[{ }^{3} \mathrm{H}\right]$ thymine and exposed to different concentrations of colicin E2. In other experiments the effect of $\mathrm{E}_{2}$ on division and DNA synthesis were measured simultaneously. Fig. I presents a composite figure of some typical results. The colicin

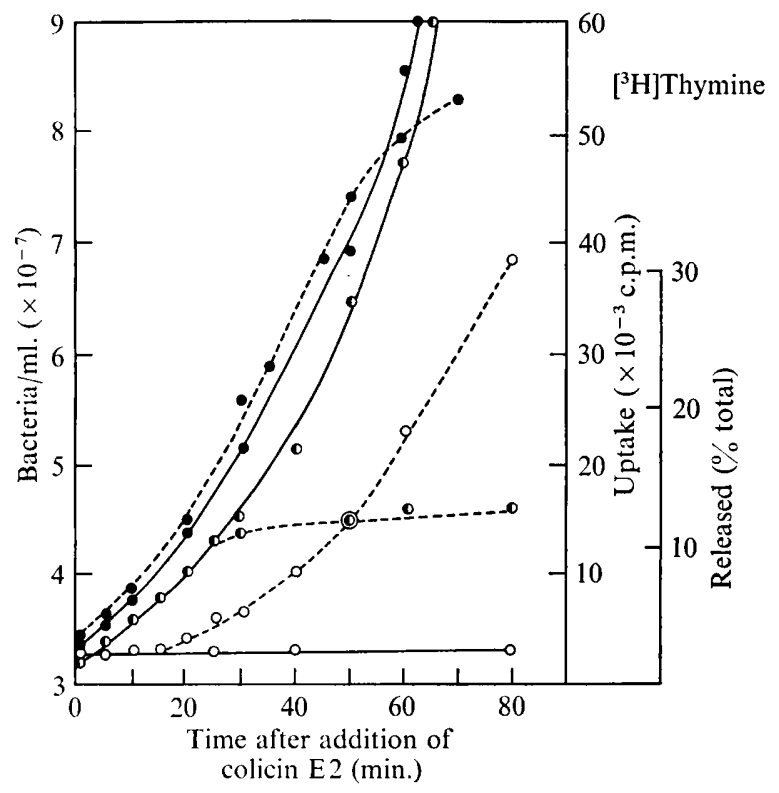

Fig. I

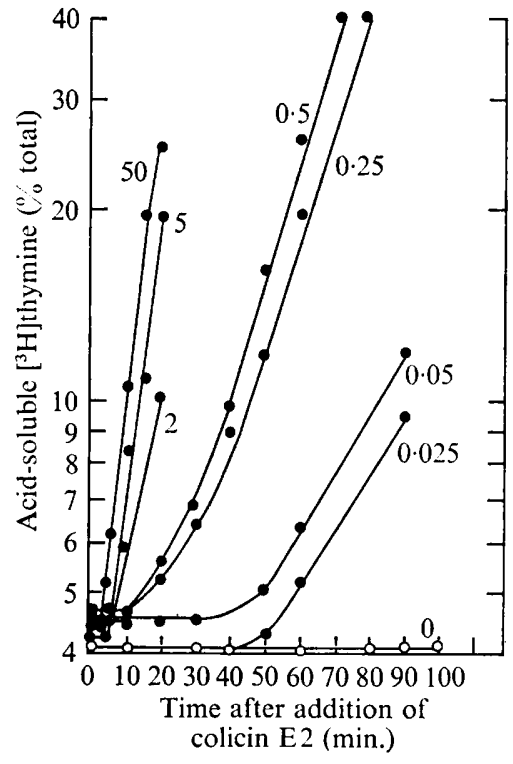

Fig. 2

Fig. I. Kinetics of colicin E2-induced DNA breakdown and inhibition of bacterial division and DNA synthesis. $\left[{ }^{3} \mathrm{H}\right]$ Thymine-labelled bacteria of Escherichia coli strain 206 were suspended in broth $+100 \mu \mathrm{g}$. cold thymine $/ \mathrm{ml}$. at $3 \times 10^{7}$ bacteria $/ \mathrm{ml}$. and treated with colicin E $2\left(0.5\right.$ units $/ 10^{7}$ bacteria) at time zero. In a parallel unlabelled culture $\left[{ }^{3} \mathrm{H}\right]$ thymine $(0 \cdot 2 \mu \mathrm{Ci} / \mu \mathrm{g}$. thymine) and $\mathrm{E} 2$ were added at zero time and samples were removed at intervals. Solid lines denote untreated controls, broken lines denote colicin-treated cultures; $O$, cold acid-soluble $\left[{ }^{3} \mathrm{H}\right]$ thymine; $\boldsymbol{\top}$, cell count; $\boldsymbol{O}$, cold acid-precipitable $\left[{ }^{3} \mathrm{H}\right]$ incorporation.

Fig. 2. Effect of colicin E2 concentration on rate of DNA breakdown in growing cultures. Exponential cultures $\left(3 \times 10^{7}\right.$ bacteria/ml.) of Escherichia coli strain 206 in nutrient broth previously labelled with $\left[{ }^{3} \mathrm{H}\right]$ thymine were treated with different concentrations of $\mathrm{E}_{2}$ at time zero. The release of soluble $\left[{ }^{3} \mathrm{H}\right]$ thymine was then determined at intervals. Figures against the curves are the $\mathrm{E}_{2}$ concentrations $/ 10^{7}$ bacteria; $\mathrm{O}$, untreated control.

concentration used in Fig. I ( 0.5 units $/ 10^{7}$ bacteria $/ \mathrm{ml}$.) was normally sufficient to kill $99 \%$ of the bacteria; DNA breakdown was first detected at 20 min. whilst the increase in bacterial number continued at the normal rate until minute 30 . Thereafter total biomass (turbidity) increased at the normal rate for at least $25 \mathrm{~min}$. and the bacteria became filamentous. DNA synthesis also continued at the normal rate for at least 
50 min. after adding E2. Similar experiments were carried out with several different concentrations of E2 and, although the time of onset of DNA breakdown varied (see also Fig. 2), the result was always the same: DNA degradation began 5 to ro min. before inhibition of division was observed. Thus inhibition of bacterial division did not appear to be a primary effect of colicin $\mathrm{E} 2$ action nor did it result from inhibition of DNA synthesis. The effect of E 2 upon the division machinery therefore remains obscure.

\section{Factors affecting initiation of DNA breakdown by E2}

Effect of E2 concentration on DNA breakdown in growing bacteria. A striking effect of colicin $\mathrm{E} 2$ action observed in these studies was that the time of commencement of DNA breakdown in exponentially growing cultures depended on the amount of $\mathrm{E}_{2}$ added. A similar effect was observed by Nomura (I964). Labelled cultures of

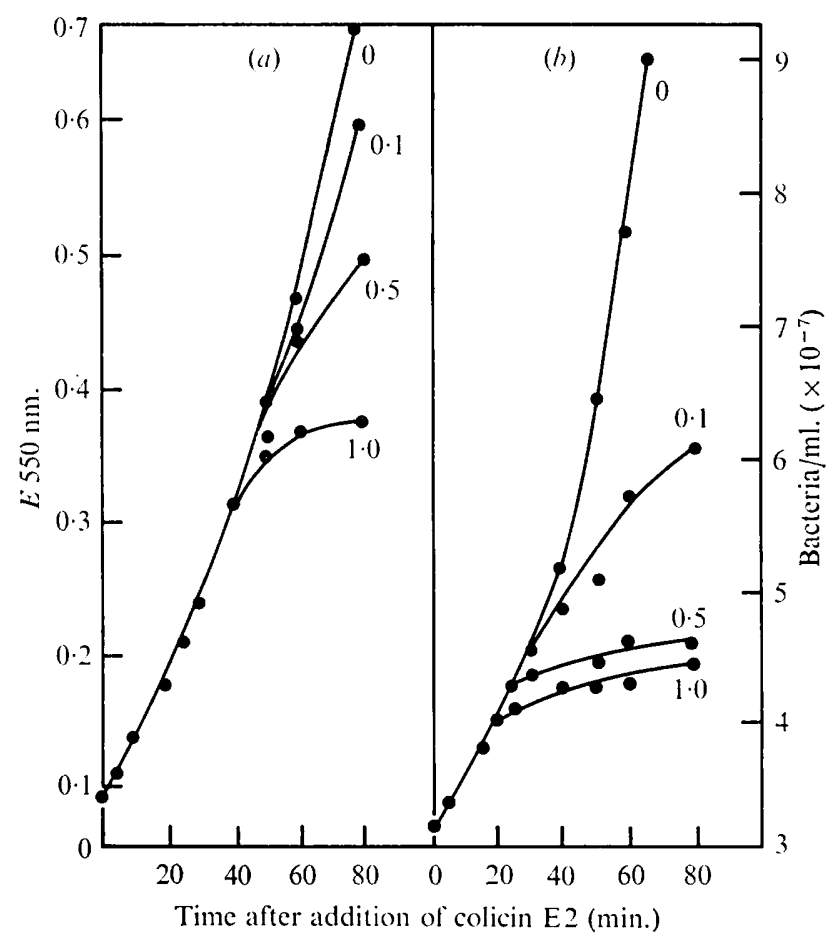

Fig. 3. Effect of colicin $\mathrm{E}_{2}$ on growth and division of exponentially growing cultures of Escherichia coli strain 206 in nutrient broth treated with $\mathrm{E}_{2}$ at time zero. Figures against the curves are the colicin concentrations added $/ 10^{7}$ bacteria; $(a)$ extinction $(E)$ rate changes, (b) total bacterial counts.

Escherichia coli strain 206 growing exponentially in nutrient broth were treated with various concentrations of $\mathrm{E}_{2}$ and the kinetics of DNA breakdown measured. Fig. 2 shows that, over a Ioo-fold range of E2 concentration, DNA breakdown was detected as early as $4 \mathrm{~min}$. or as late as $50 \mathrm{~min}$. (equivalent to $\mathrm{I} \cdot 5$ generations). Similar results were obtained even when adsorption of $\mathrm{E} 2$ was done at $4^{\circ}$ and the bacteria washed to remove excess $\mathrm{E}_{2}$ before raising the temperature to $37^{\circ}$. Measurement of the survival 
kinetics of bacteria treated with various $\mathrm{E}_{2}$ concentrations also showed that the delayed induction of DNA breakdown by small amounts of E2 was not due to slow adsorption of the colicin. When the effect of E2 upon bacterial division was measured at different colicin concentrations, similar results to those on the induction of DNA breakdown were obtained. Addition of $\mathrm{E}_{2}$ was followed by normal increases in bacterial number until, abruptly, the rate of increase changed at a time determined in some way by the amount of $\mathrm{E} 2$ present (Fig. 3).

\section{Table I. Effect of colicin E2 multiplicity on induction of DNA breakdown}

Exponential broth cultures of Escherichia coli strain $206\left(3 \times 10^{7}\right.$ bacteria $/ \mathrm{ml}$. $)$ treated at time zero with colicin $\mathrm{E}_{2}$ at $37^{\circ}$ as in Fig. 2. Rates of DNA breakdown calculated from the slopes of the curves shown in Fig. 2.

$\begin{array}{cr}\begin{array}{c}\text { Units } / \mathrm{I}^{7} \\ \text { bacteria }\end{array} & \begin{array}{r}\text { Estimated no. } \\ \text { molecules/ } \\ \text { bacterium }\end{array} \\ 0.025 & 25 \\ 0.05 & 50 \\ 0.1 & 100 \\ 0.25 & 250 \\ 0.5 & 500 \\ 5 & 5,000 \\ 50 & 50,000\end{array}$

$\begin{array}{ccc}\begin{array}{c}\text { Bacterial } \\ \text { survival } \\ \text { (after } 60 \mathrm{~min} .)\end{array} & \begin{array}{c}\text { Time of onset } \\ \text { (min.) }\end{array} & \begin{array}{c}\text { Rate \% sol. } \\ {\left[{ }^{3} \mathrm{H}\right] \text { thymine }} \\ \text { released } / \mathrm{min} .\end{array} \\ 53 \% & 45 & 0.16 \\ 23 \% & 40 & 0.2 \mathrm{I} \\ 16 \% & 20 & 0.37 \\ 0.4 \% & 10 & 0.42 \\ 0.1 \% & 10 & 0.62 \\ 0.01 \% & 5 & 0.86 \\ 0.001 \% & 4 & 1 \cdot 23\end{array}$

This effect of concentration of colicin $\mathrm{E}_{2}$ on the pattern of DNA breakdown in sensitive bacteria was investigated in many experiments, and the relationship between E 2 concentration, the timing of DNA breakdown and the subsequent rate of this process is examined in Table 1 , which also shows the bactericidal effect of $\mathrm{E}_{2}$ and presents each colicin concentration as the number of $\mathrm{E}_{2}$ molecules/cell. This can be estimated since the molecular weight of $\mathrm{E}_{2}$ is known (Herschman \& Helinski, 1967) and the specific activity of purified $\mathrm{E}_{2}$ (I000 units $/ \mu \mathrm{g}$. protein) was determined previously (Holland, I968). On the basis of these calculations, the maximum number of $\mathrm{E}_{2}$ molecules adsorbed/organism was 2000 , which is in good agreement with the figure of 2000 to 3000 E 2 receptors calculated by Maeda \& Nomura (I966). The results in Table I show that when sufficient $\mathrm{E}_{2}$ was added to saturate all receptors there was a minimum delay of $4 \mathrm{~min}$. before breakdown was detected. At E2 concentrations sufficient to kill only $47 \%$ of the bacteria, less than $5 \%$ of the receptors should be occupied, and in this case breakdown was only detected at $40 \mathrm{~min}$. These results indicate that, with exponentially growing bacteria, very few of the initial receptor colicin complexes promoted a lethal interaction between colicin and membrane. At high $\mathrm{E} 2$ concentrations, at least one lethal hit was quickly attained but at subsaturation concentrations growth and division appeared to be needed before a lethal hit, as expressed by the induction of DNA breakdown, took place. The data in Table I also show that, in contrast to its effect upon the timing of breakdown, increasing the concentration of $\mathrm{E}_{2}$ did not greatly influence the rate of DNA breakdown. Although E2, when added in excess, stimulated higher rates of breakdown, at subsaturation concentrations the rate of degradation was virtually independent of the $\mathrm{E} 2$ concentration, particularly when the fraction of bacteria killed by the colicin is taken into account. 
These results do not rule out the possibility that DNA breakdown was initiated by the co-operative effect, upon the membrane, of many colicin molecules, i.e. a multihit mechanism. Since, however, there is evidence that the killing action of colicin is a single-hit process (Jacob, Siminovitch \& Wollman, I952; Nomura, I963; Shannon \& Hedges, 1967), we favour the alternative interpretation that DNA degradation is initiated by an all or none process, and that in growing cultures the main effect of increasing the $\mathrm{E}_{2}$ concentration was to increase the probability of an early single hit which then initiated DNA breakdown (or inhibition of division) at the maximum rate.

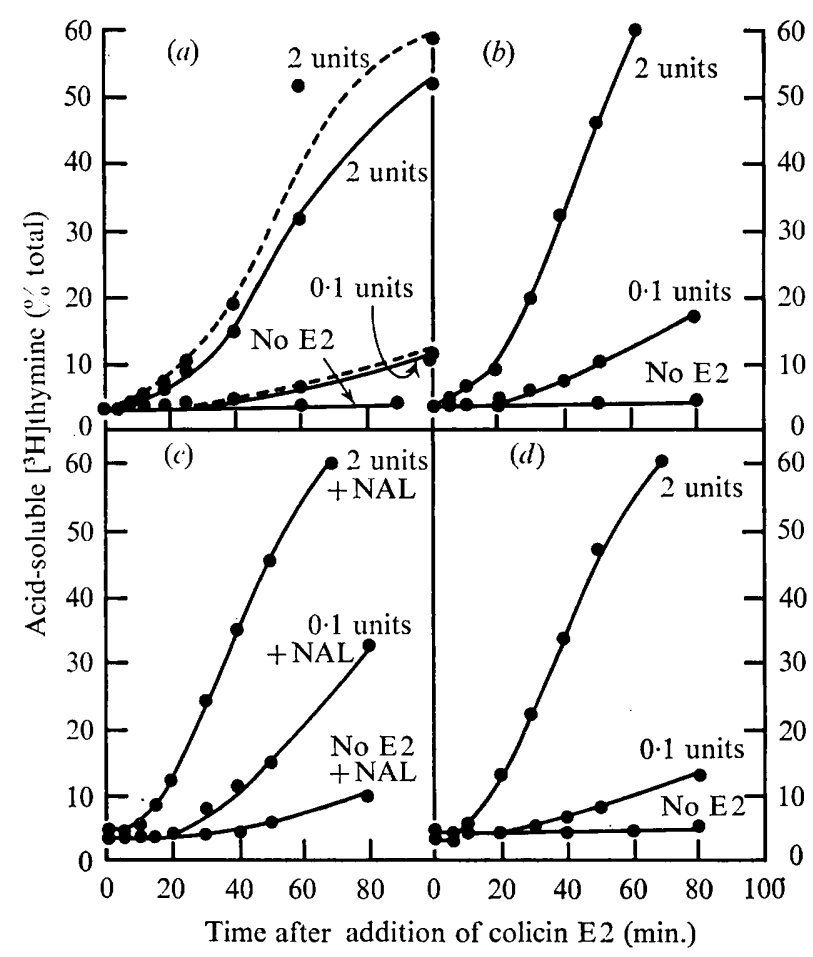

Fig. 4. Effect of chloramphenicol and nalidixic acid on colicin E2 action. Cultures of Escherichia coli strain 206 growing exponentially in nutrient broth were labelled with $\left[{ }^{3} \mathrm{H}\right]$ thymine. (a) Chloramphenicol (200 $\mu \mathrm{g} . / \mathrm{ml}$.) was added to cultures (broken lines) at - IO min.; colicin E2 was added to all cultures at time zero and release of cold acidsoluble $\left[{ }^{3} \mathrm{H}\right]$ thymine determined at intervals. Colicin $\mathrm{E}_{2}$ concentration $/ \mathrm{IO}^{7}$ bacteria is indicated for each curve. (c) Nalidixic acid (NAL) $(20 \mu \mathrm{g} . / \mathrm{ml}$.) was added to cultures at $-2 \mathrm{~min}$. followed by E2 at time zero. (d) Cultures first treated with NAL $(20 \mu \mathrm{g} . / \mathrm{ml}$.) for $30 \mathrm{~min}$.; NAL was then removed by centrifugation, cultures resuspended in nutrient broth and $E_{2}, 2$ and 0.1 units $/ 10^{7}$ bacteria, added at time zero. The control received no colicin. (b) Cultures treated with $\mathrm{E}_{2}$ alone (controls for the NAL treatments).

Effect of inhibition of DNA and protein synthesis upon E2-induced DNA breakdown. Energy is required for the conversion of the initial colicin E2-cell complex into a state from which viable bacteria can no longer be recovered by trypsin action (Reynolds \& Reeves, 1969). Nomura \& Maeda (1965) have shown that no DNA breakdown takes place in bacteria treated with $\mathrm{E}_{2}$ in the presence of 2,4-dinitrophenol. In addition, the results described in the previous section indicate that, particularly at low concentrations of $E_{2}$, some growth was required to initiate DNA breakdown. The question whether 
protein synthesis was needed for the formation of, for example, a specific colicinsurface complex or for the synthesis de novo of a specific DNase was therefore studied. Cultures prelabelled with $\left[{ }^{3} \mathrm{H}\right]$ thymine were exposed to different concentrations of colicin E 2 with chloramphenicol ( $200 \mu \mathrm{g}$./ml.). As shown in Fig. 4, neither the length of the prebreakdown lag nor the subsequent rate of breakdown were affected. In a few experiments chloramphenicol did produce some decrease in rate of breakdown, particularly with low $\mathrm{E} 2$ concentrations, but this effect was not reproducible and may have been due to disturbance in the growth of the bacterial surface induced by chloramphenicol (see Rothfield \& Pearlman-Kathencz, 1969). Amino acid starvation before and during treatment with colicin E2 was also without effect upon the DNA breakdown pattern. These results clearly showed that the promotion of DNA breakdown by $\mathrm{E} 2$ did not require the synthesis de novo of a DNase. In addition, these results showed that the lag period before the initiation of DNA breakdown by low $\mathrm{E} 2$ concentrations was apparently not associated with the synthesis of any cellular protein component.

The effect of inhibition of DNA synthesis upon colicin E2 action is also shown in Fig. 4. Labelled cultures of Escherichia coli strain 206 were exposed to E2 after treatment in various ways with nalidixic acid (NAL). NAL did not inhibit DNA breakdown induced by high or low E2 concentrations. Furthermore, experiments discussed below showed that E2-induced DNA breakdown proceeded normally at $42^{\circ}$ in mutants defective in ability to replicate DNA at high temperature. Promotion of DNA breakdown by $E 2$ could therefore be initiated at any point in the DNA replication cycle and degradation did not depend upon continued synthesis. Fig. $4 d$ also shows that pretreatment with NAL under conditions which promoted more chromosomal replication forks per bacterium (see Pritchard, Barth \& Collins, 1969) did not stimulate the rate of DNA breakdown on subsequent addition of colicin E 2 . This result suggests that DNA breakdown in E2-treated bacteria is not specifically triggered from the replication point on the chromosome.

Induction of DNA breakdown by E2 in non-growing bacteria. The results described above indicated that, particularly at low E 2 concentrations, initiation of DNA breakdown depended on growth or accumulation of some cellular component. This interpretation predicted that, in non-growing bacteria (e.g. in buffer suspensions), high E 2 concentrations should initiate breakdown more or less normally, but small amounts of $E_{2}$ should initiate breakdown only poorly. Contrary to expectation, as shown in Fig. 5, extensive breakdown of DNA was observed with both high and low E 2 concentrations. In the latter case the delay in initiation of breakdown observed in growing bacteria was not found, and soluble $\left[{ }^{3} \mathrm{H}\right]$ thymine was detected in all cultures within a few minutes of adding E2. DNA breakdown in buffered suspensions quickly became linear in contrast to the exponential rates found with growing bacteria. Nevertheless, initial rates were usually at least half those for broth suspensions treated with comparable E 2 concentrations. Again, as found with growing bacteria, the rate of DNA breakdown in buffer suspension was not very dependent upon the colicin concentration: over at least a 100-fold range of $\mathrm{E} 2$ concentration the rate of DNA breakdown increased at most sixfold.

The long delays in initiation of DNA breakdown observed in broth cultures were thus due to some effect unique to growing bacteria and were not essential for E2 action. Possible explanations for the effect of $\mathrm{E}_{2}$ multiplicity upon the timing of initiation of DNA breakdown will be discussed below. 
Effect of phosphate on initiation of DNA breakdown in buffer suspensions. Bacteria in tris $+\mathrm{HCl}$ buffer showed very little DNA breakdown in the presence of colicin $\mathrm{E} 2$ although adsorption and killing by $\mathrm{E}_{2}$ were normal. Addition of $\mathrm{KH}_{2} \mathrm{PO}_{4}$ to treated bacteria in tris $+\mathrm{HCl}$ buffer stimulated DNA breakdown, and rates comparable to those in phosphate buffer were obtained with $\mathrm{IO}^{-2} \mathrm{M}$-phosphate. As shown in Fig. 6, $\mathrm{KH}_{2} \mathrm{AsO}_{4}$ was quite effective in stimulating breakdown in tris buffer, in contrast to $\mathrm{NaCl}, \mathrm{KCl}$ or lower concentrations of $\mathrm{KH}_{2} \mathrm{PO}_{4}$. The stimulation produced by added phosphate was usually six- to eightfold although in a few experiments DNA breakdown in tris buffer alone was more extensive, and the effective stimulation by added phosphate was only two- to threefold.

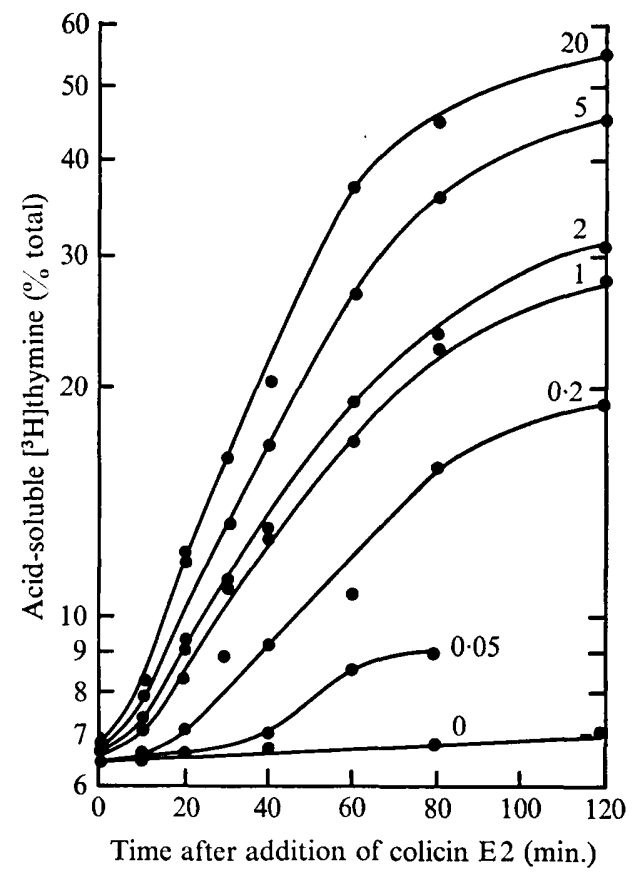

Fig. 5

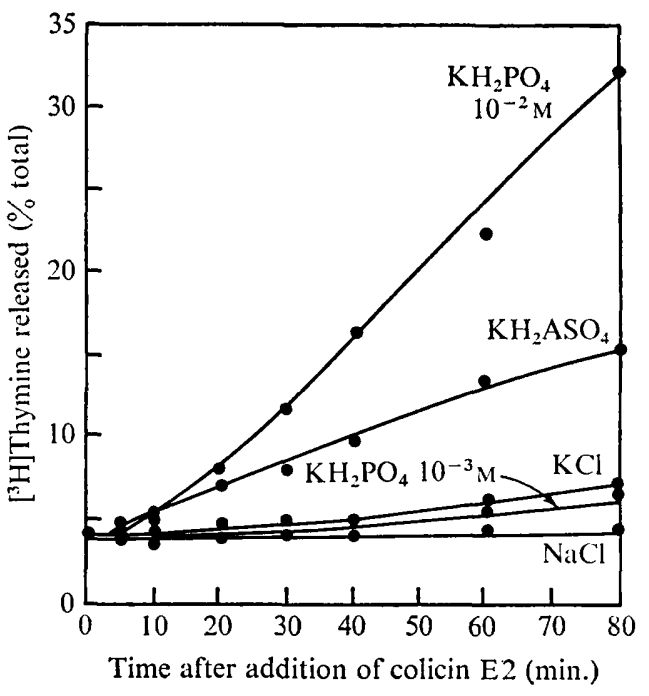

Fig. 6

Fig. 5. Induction of DNA breakdown by colicin $\mathrm{E}_{2}$ in resting bacteria. Growing cultures of Escherichia coli strain 206 were labelled in the usual way, harvested, washed three times in $0 \cdot 1 \mathrm{M}$-tris buffer $\left(\mathrm{pH}_{7} \cdot 2\right.$ ) containing $1 \mathrm{O}^{-2} \mathrm{M}-\mathrm{KH}_{2} \mathrm{PO}_{4}, \mathrm{IO}^{-3} \mathrm{M}-\mathrm{MgSO}_{4}$ and $\mathrm{IO}^{-4} \mathrm{M}-$ $\mathrm{CaCl}_{2}$ and the bacteria finally resuspended to $2 \times 10^{7} / \mathrm{ml}$. in the same buffer $+25 \mu \mathrm{g}$. cold thymine $/ \mathrm{ml}$. After incubation for $10 \mathrm{~min}$. at $37^{\circ}$, colicin E2, diluted in buffer, was added at time zero. Incubation was continued at $37^{\circ}$ and release of labelled thymine determined at intervals. The figures by the curves are the colicin concentrations $/ 10^{7}$ bacteria.

Fig. 6. Effect of anions on induction of DNA breakdown by colicin E2. Isotopically labelled cultures of Escherichia coli strain 206 were washed three times in $0^{\circ} \mathrm{I}$ M-tris buffer $\left(\mathrm{pH} 7 \cdot 2\right.$ ) and resuspended in the same buffer containing $25 \mu \mathrm{g}$. thymine $/ \mathrm{ml}^{\text {., }} 1 \mathrm{IO}^{-3} \mathrm{M}-\mathrm{MgSO}_{4}$, $10^{-4} \mathrm{M}-\mathrm{CaCl}_{2}$. After shaking cultures at $37^{\circ}$ for $\mathrm{IO}$ min., different samples received $\mathrm{NaCl}$, $\mathrm{KCl}, \mathrm{KH}_{2} \mathrm{AsO}_{4}$ (all $10^{-2} \mathrm{M}$ ) or $\mathrm{KH}_{2} \mathrm{PO}_{4}\left(10^{-2}\right.$, $10^{-3} \mathrm{M}$ ). Colicin $\mathrm{E}_{2}$ added to 5 units $/ 10^{7}$ bacteria at time zero.

In an attempt to determine which particular step in the $E_{2}$ pathway was affected, the kinetics of inactivation of bacteria treated with $\mathrm{E}_{2}$ in tris buffer were examined and found to be similar whether phosphate was present or not. Phosphate was not 
therefore required for irreversible binding of colicin E 2. Similarly, phosphate was not required for the degradative process itself since removal of phosphate from the suspending medium after the onset of breakdown did not affect further degradation (Table 2). Several experiments, however, indicated that exogenous phosphate was required for formation of the specific colicin-envelope complex which rapidly initiated phosphate-independent DNA breakdown. Table 2 also shows: (I) suspension of bacteria in phosphate buffer did not stimulate DNA breakdown when exogenous phosphate was removed before addition of E 2; (2) phosphate starvation of bacteria for at least $30 \mathrm{~min}$. before addition of $\mathrm{E}_{2}$ did not affect subsequent phosphate stimulation of DNA breakdown; (3) after preadsorption of E2, bacteria showed increased DNA breakdown immediately upon addition of phosphate; treatment of organisms with $\mathrm{E} 2$ in the presence of phosphate at $4^{\circ}$ did not stimulate subsequent DNA breakdown when phosphate was removed before incubation at $37^{\circ}$.

\section{Table 2. Effect of phosphate on initiation of DNA breakdown by colicin E2}

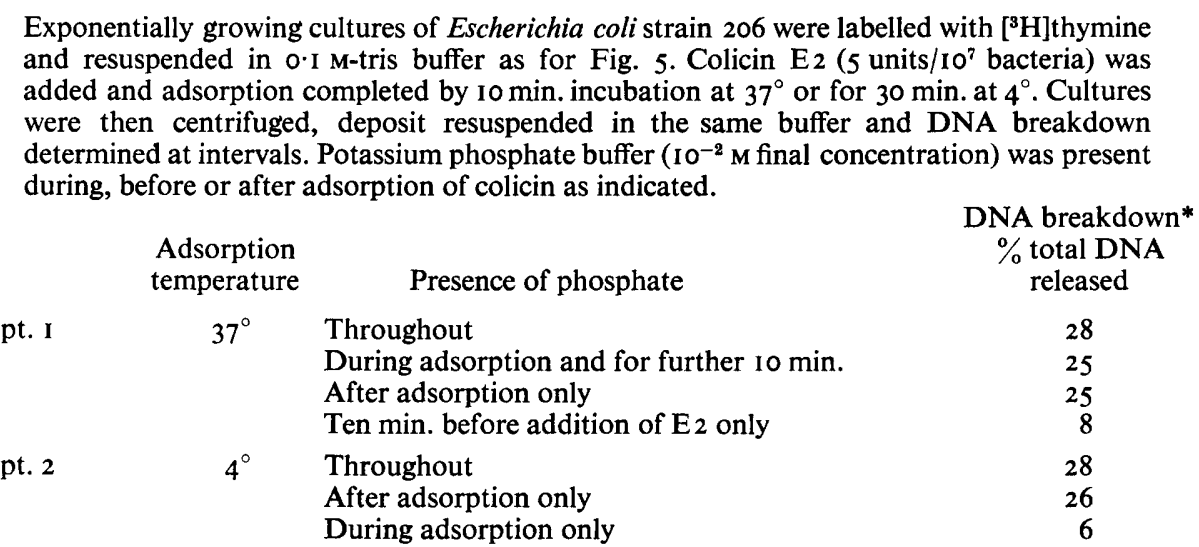

\footnotetext{
* The amount of breakdown shown is that obtained after $90 \mathrm{~min}$. postadsorption incubation at $37^{\circ}$. When phosphate was present throughout, the amount of breakdown obtained was 25 to $40 \%$ over several experiments; without phosphate, between 3 and $8 \%$ of DNA was usually broken down in $90 \mathrm{~min}$. at $37^{\circ}$.
}

In summary, the above results indicate that, in bacteria suspended in tris buffer, the initial colicin-cell complex was only poorly active in initiating DNA breakdown. In the presence of exogenous phosphate, a temperature-dependent process then converted the colicin-surface complex into an active form which promoted DNA breakdown.

\section{Mechanism of DNA breakdown in bacteria treated with colicin E2}

The degradative process requires energy. Since earlier studies showed that energy was required to promote colicin $\mathrm{E}_{2}$ action, the possibility was examined that the DNA breakdown process itself might be energy-dependent. As shown in Fig. 7, 2,4-dinitrophenol (DNP) immediately and dramatically decreased the rate of breakdown by treated bacteria. The effect was reversible and upon removal of DNP, breakdown immediately resumed at the original rate (Fig. $7 b$ ). Fig. $7 a$ shows that DNP was equally effective in suppressing breakdown when added at late times. The breakdown 
process itself is therefore inhibited by DNP. Energy metabolism in E 2-treated bacteria was also inhibited at various times by cyanide $\left(2 \times 10^{-3} \mathrm{M}\right.$ ) or colicin $\mathrm{K}$ (an uncoupler of oxidative phosphorylation; see Levinthal \& Levinthal cited by Luria, 1964) and in each case the rate of breakdown was greatly decreased, confirming that energy is required to maintain the colicin-membrane-DNA complex in a state propitious for breakdown, or alternatively that the E2-specific nuclease itself is ATP-dependent.

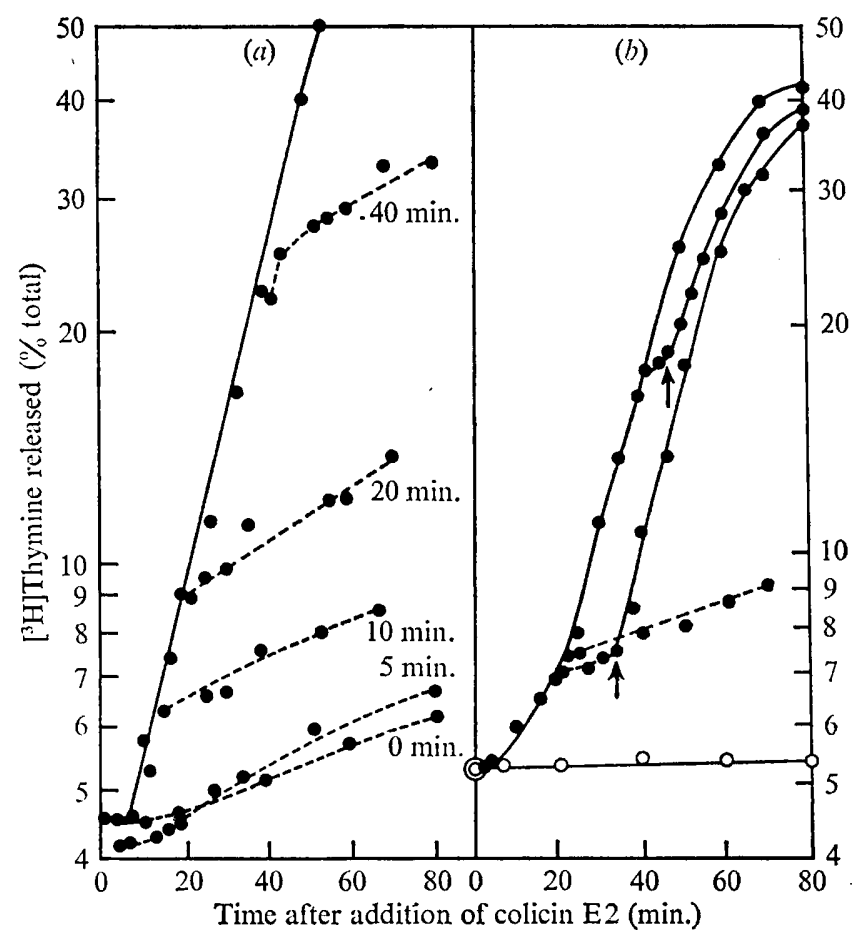

Fig. 7. Effect of inhibition of energy metabolism upon colicin E2-induced DNA breakdown. (a) Exponential cultures $\left(2 \times 10^{7}\right.$ bacteria/ml.) of Escherichia coli strain 206 in nutrient broth at $37^{\circ}$ were treated with colicin E2 (2 units $/ 10^{7}$ bacteria) at time zero, - At the intervals indicated by the curves --- , 2,4-dinitrophenol (DNP) (final concentration $2 \times 10^{-3} \mathrm{M}$ ) was added. Release of acid-soluble $\left[{ }^{3} \mathrm{H}\right]$ thymine was then measured as described in Methods. (b) Strain 206 in nutrient broth treated with E 2 (2 units/10 $0^{7}$ bacteria/ $\mathrm{ml}$.). Separate fractions were treated with DNP at $20 \mathrm{~min}$. and at $40 \mathrm{~min}$.; duration of DNP treatment is indicated by broken lines. At the times indicated by arrows, DNP was removed by centrifugation and incubation of bacteria in nutrient broth resumed. The control culture (O) was treated with DNP only.

Effect of trypsin on E2-induced DNA breakdown. Nomura \& Nakamura (1962) previously showed that macromolecule synthesis, completely suppressed by colicin $\mathrm{K}$, was quickly resumed after addition of trypsin. The membrane alteration induced by colicin $\mathrm{K}$ is therefore only maintained in its presence and reverts to normal when it is removed. Since a primary consequence of colicin E 2 action is the promotion of DNA breakdown, we determined whether nuclease activity also depended completely upon the continued presence of E2. In the presence of small amounts of E2 (Fig. $8 a$ ), addition of trypsin to Escherichia coli strain 206 greatly inhibited further breakdown even when added at $30 \mathrm{~min}$.; during the early lag period it completely 
suppressed DNA breakdown. This latter effect provides further confirmation that the formation of an active surface-E2 complex, which promotes DNA breakdown, is delayed at low E2 concentrations. At saturating concentrations of E2, trypsin was most effective when added up to Io min. after initiation of breakdown and, as shown in Fig. $8 b$, was progressively less effective when added at later times. Phase-contrast

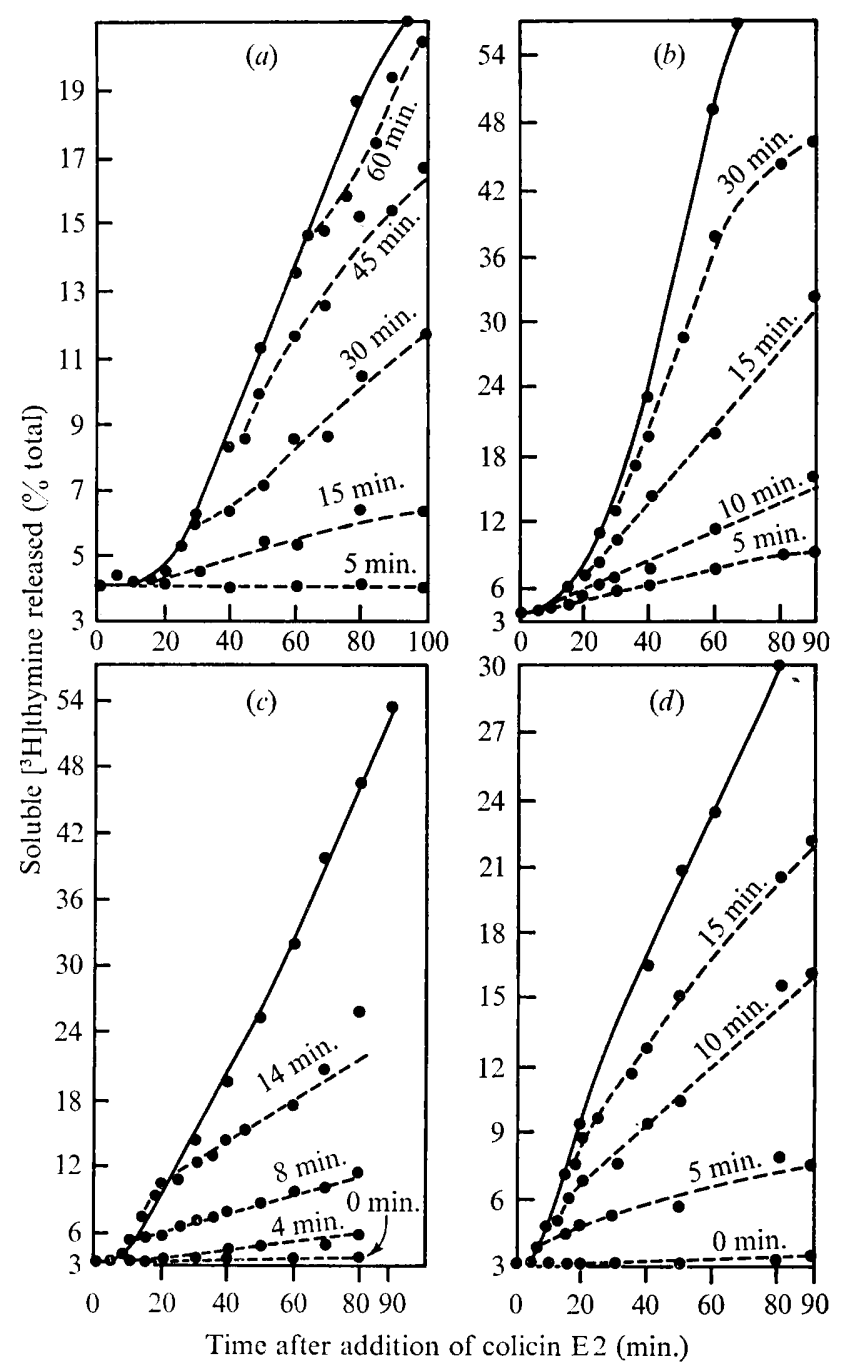

Fig. 8. Effect of trypsin on colicin E2-induced DNA breakdown. Cultures of Escherichia coli strain 206 were labelled in the usual way, washed and suspended in nutrient broth, $\mathrm{pH} 7.8(a, b)$, or in tris buffer, $\mathrm{pH} 7.8(c, d)$, containing $10^{-2} \mathrm{M}_{-} \mathrm{KH}_{2} \mathrm{PO}_{4}, 1^{-3} \mathrm{M}-\mathrm{MgSO}_{4}$ and $\mathrm{IO}^{-4} \mathrm{M}_{-} \mathrm{CaCl}_{2}$. Solid lines represent the primary cultures treated with colicin $\mathrm{E}_{2}$, broken lines denote samples removed from primary culture and treated with trypsin ( $\mathrm{I} \mathrm{mg} . / \mathrm{ml}$.). (a) Nutrient broth culture treated with colicin $\mathrm{E}_{2}\left(0.2\right.$ units $/ 10^{7}$ bacteria) at zero time and trypsin treatment done at the times indicated. (b) Nutrient broth cultures treated with E2 ( 2 units $/ 10^{7}$ bacteria). (c) Bacteria suspended in tris phosphate buffer and treated with $\mathrm{E}_{2}$ (8 units $/ 10^{7}$ bacteria). (d) Preadsorption of E2 (Io units $/ 10^{7}$ bacteria) for $45 \mathrm{~min}$. at $4^{\circ}$, cultures then centrifuged and deposit suspended in tris phosphate buffer before trypsin treatment. 
microscopy of such cultures showed that trypsin was also most effective in preventing filament formation when added early.

Three possible explanations of these features of trypsin inhibition are: (I) initiation of DNA breakdown is not synchronized in all of the population, and trypsin only affects those bacteria in which $\mathrm{E}$ 2-induction of DNA breakdown is not yet established; (2) colicin $\mathrm{E} 2$ becomes, with time, increasingly inaccessible to the trypsin molecule; (3) the specificity of the degradative process is progressively lost as breakdown becomes extensive.

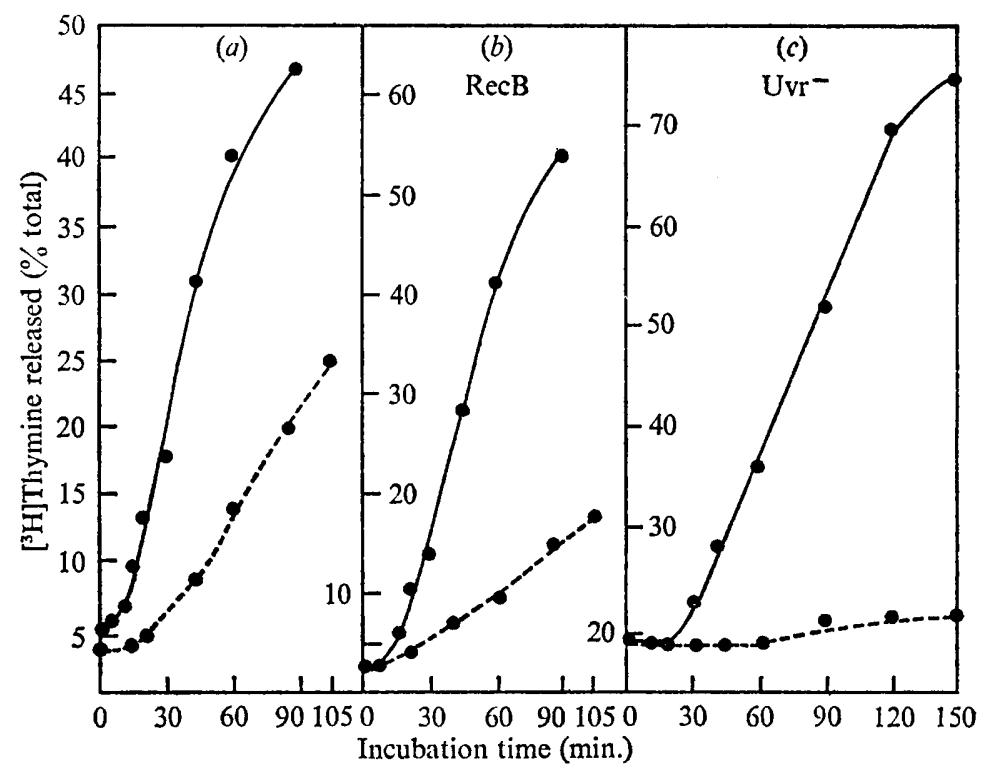

Fig. 9. Mitomycin C and colicin E2-induced DNA breakdown in Rec and Uvr mutants of Escherichia coli. Bacterial strains labelled with $\left[{ }^{3} \mathrm{H}\right]$ thymine in the usual way and colicin E 2 ( 5 units $/ 10^{7}$ bacteria) or mitomycin C ( $40 \mu \mathrm{g} . / \mathrm{ml}$.) added at time zero. Solid lines denote E2-treated, broken lines mitomycin C-treated cultures. (a) Wild-type strain 206; (b) Strain JC4457, RecB-; (c) Strain KMBL90, UvrB-.

In an attempt to test the first possibility, the effect of trypsin on E 2 action in nongrowing bacteria was examined in the hope that any asynchrony arising from some aspect of growth would be minimal. The effect of trypsin upon DNA breakdown was, however, very similar to that obtained with growing cultures (Fig. $8 \mathrm{c}$ ). Early addition of trypsin completely abolished subsequent breakdown, and the trypsin effect was progressively lost as breakdown proceeded. Nevertheless, even when breakdown was well under way, addition of trypsin still produced a significant, although sometimes delayed, inhibitory effect. Similar results were obtained when adsorption of E 2 was completed at $4^{\circ}$ and non-adsorbed $\mathrm{E} 2$ removed by centrifugation before shifting the treated bacteria to $37^{\circ}$, conditions under which colicin is irreversibly adsorbed although at a slower rate. It therefore seems unlikely that trypsin affects only those bacteria in which DNA degradation has not yet been initiated.

Several relevant control experiments were also made: (a) under the cultural conditions normally used, trypsin treatment had no effect upon mitomycin C-induced DNA breakdown; (b) with E2-treated bacteria, subsequent removal of trypsin did not lead 
to a resumption of the normal rate of DNA breakdown, and when equimolar amounts of trypsin and trypsin inhibitor were added breakdown was not inhibited; (c) incubation of bacteria with trypsin followed by removal of the enzyme and addition of colicin E2 had no inhibitory effect upon subsequent DNA degradation.

The observed effects of trypsin upon colicin E2 action appear therefore to be the result of the proteolytic digestion of the surface-bound colicin and not to any nonspecific effects. On the basis of all these results it seems reasonable to conclude that, at least at early times, removal of $\mathrm{E}_{2}$ by trypsin treatment can have a direct inhibitory effect upon the E2-specific nuclease.

Effect of E2 on Escherichia coli $K 12$ mutants defective in nuclease functions. A number of strains of Escherichia coli mutants possibly lacking nuclease functions (see Table 3) have been studied. All of them were sensitive to colicin $E_{2}$ and showed normal E2induced DNA breakdown at $37^{\circ}$ (or at $42^{\circ}$ in the case of temperature-sensitive DNAreplication mutants) including strains which lack an ATP-dependent nuclease (Buttin

\section{Table 3. Escherichia coli mutants tested for colicin E2-sensitivity and E2-induced DNA breakdown}

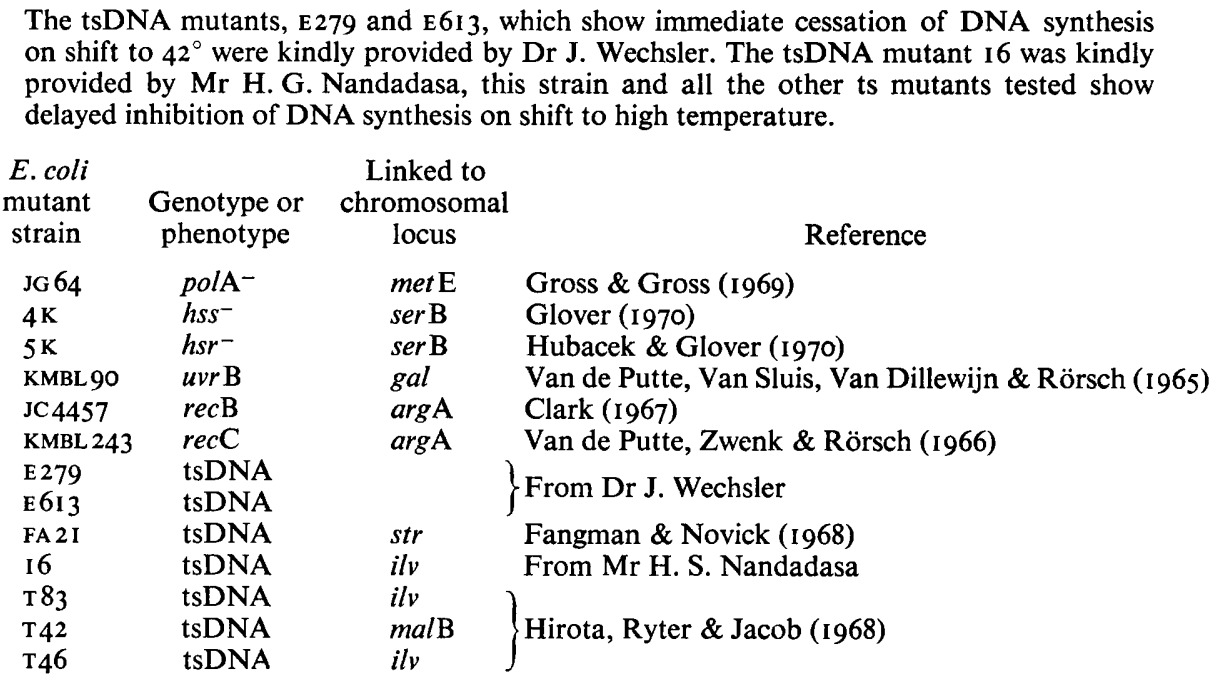

\& Wright, 1968) and restriction-deficient strains, which probably lack an ATPdependent endonuclease (Meselson \& Yuan, I968). As found previously, colicin E2 also promoted normal breakdown in a Uvr- mutant (Holland, 1967) although mitomycin C-induced DNA breakdown was greatly decreased compared to wild-type strains (Fig. 9). Uvr ${ }^{-}$mutants appear to lack the capacity to excise thymine dimers (Howard-Flanders \& Theriot, I966) and to repair mitomycin C-induced damage (Boyce \& Howard-Flanders, 1964), and since such mutants show normal sensitivity to colicin $\mathrm{E}_{2}$ it appears most unlikely that E2-directed DNA breakdown involves any of the normal repair nucleases. Several mutants that were temperature-sensitive for DNA replication were also examined, including mutants possibly defective in either replication or the initiation of replication (Table 3), but all showed normal E2-induced DNA breakdown at high temperature. 


\section{DISCUSSION}

\section{Factors affecting initiation of DNA breakdown by colicin $\mathbf{E 2}$}

On the basis of our studies and those of other workers, we envisage the following scheme for the pathway of colicin $\mathrm{E}_{2}$ action:

bacteria $+\mathrm{E}_{2} \rightarrow$ Surface complex I $\rightarrow$ Surface complex II (promotes DNA breakdown).

The initial adsorption step is a two-stage process (Reynolds \& Reeves, I969) leading to an irreversible state, complex I. This appears to require magnesium (Reynolds \& Reeves, 1969) but not energy and is completely reversible by trypsin treatment. The specificity for complex I is shared by colicin E2 and E 3 (Maeda \& Nomura, I966), although the two colicins have quite different intracellular effects. The chemical nature of the primary receptor is not known but it may well be analogous to a phage receptor. Some intermediate stages, presumably involving interaction between $\mathrm{E}_{2}$ and specific membrane proteins, may then be involved before the pathway culminates in the formation of complex II, a conformational state of the membrane which promotes rapid degradation of DNA and inhibition of cell division.

The formation of complex II is a complicated process, the efficiency and timing of which varies in relation to the colicin concentration and to the physiological conditions of the organism. Nevertheless, the initiation of DNA breakdown always appears to be an all-or-none process, with increasing concentrations of colicin $\mathrm{E}_{2}$ hastening initiation of breakdown rather than its ultimate rate. Although this multiplicity effect of $\mathrm{E}_{2}$ is not understood, it is clear that synthesis of neither protein nor DNA is required for the development of the final surface complex which triggers DNA breakdown. Differential growth or extension of various surface layers in the presence of small concentrations of E2 may, however, be important in determining the timing of complex II formation, but it cannot be an absolute requirement since in non-growing bacteria low doses of $\mathrm{E}_{2}$ still trigger DNA breakdown without appreciable delay.

It is still not clear whether complex II formation is energy-dependent. Promotion of E2 action is temperature-dependent and is inhibited by 2,4-dinitrophenol, but the finding that the DNA breakdown process itself requires energy makes it difficult to establish whether any of the intermediate steps are also energy-requiring.

Genetic analyses have previously shown that mutants refractory to colicin E 2 may be blocked at several postadsorption steps (Hill \& Holland, 1967; Nomura \& Witten, 1967; Nagel de Zwaig \& Luria, 1967) probably by alteration of specific proteins (Nomura \& Witten, I967; Holland, 1968; Nagel de Zwaig \& Luria, 1969). Recent biochemical studies have shown that refractory mutants may lack or contain altered membrane proteins (Samson \& Holland, I970; C. Schnaitman, personal communication), suggesting that membrane or surface proteins may participate in complex II formation. Colicin E2 may therefore not interact directly with a membrane-bound nuclease but may act indirectly through the intermediacy of specific membrane proteins, possibly as suggested by Changeux \& Thiery (1967) via conformational changes of repeating membrane protomers, leading to a final specific protein or membrane configuration which then promotes nuclease action. The finding that resting bacteria in tris buffer require added phosphate for efficient initiation of DNA breakdown but not for adsorption of colicin, provides further evidence for the presence of intermediate steps in $\mathrm{E} 2$ action. 
We have suggested above that the final formation of complex II simply involves a series of physical changes in the cell membrane in response to the fixation of colicin. Several lines of evidence suggest that the ultimate biochemical changes induced by different colicins, including $\mathrm{E}$ 2, derive from the altered properties of membrane-bound proteins or enzymes in situ and not from the activities of, for example, enzymes displaced from the membrane and acting through the cytoplasm. Thus the effects of colicin $\mathrm{K}$ upon energy metabolism and macromolecular synthesis are completely reversed upon subsequent removal of the colicin from the cell surface by trypsin treatment (Nomura \& Nakamura, 1962). Moreover, although modification of $30 \mathrm{~S}$ ribosomal subunits is induced by colicin $\mathrm{E}_{3}$ fixation to sensitive bacteria, extracts from such bacteria are incapable of modifying normal ribosomes in vitro (Konisky \& Nomura, 1967). DNA breakdown induced by colicin E 2 can, at least in the early stages, be halted or decreased by digestion of the adsorbed colicin with trypsin. Thus it appears that the membrane conformation induced by colicin E 2 may return, as in the case of colicins $\mathrm{E}_{\mathrm{I}}$ and $\mathrm{K}$, to its original state when colicin is removed. The failure of trypsin to inhibit DNA breakdown effectively when added at later times is unexplained; asynchronous initiation of DNA breakdown within the population appears to be excluded as a major factor. More likely, the specificity of the degradative process is soon lost or the colicin becomes inaccessible to trypsin as DNA breakdown proceeds and division is halted.

\section{Specificity of E2-induced DNA breakdown}

With the formation of complex II the altered membrane induces rapid degradation of DNA and, as a consequence or as an independent effect, the inhibition of division. The degradative process appears to be highly specific to the Escherichia coli chromosome; in T4-infected bacteria colicin E 2 does not promote phage DNA breakdown (Nomura, 1963), and invading $\lambda$ DNA is not degraded in E2-treated bacteria and appears to replicate normally (unpublished results). Also, since DNA replication may continue in E2-treated bacteria without loss of newly synthesized strands until at least $10 \%$ of the chromosome is degraded (Fig. I), it appears probable that breakdown is initiated at a few strictly localized sites, possibly at the replication fork or at the chromosomal origin, both of which have been shown to be membrane-bound (Sueoka \& Quinn, 1968). The kinetics of breakdown of pulse-labelled DNA in colicin E2treated bacteria (unpublished results), however, indicate that breakdown does not begin at the replication fork, unless recently copied parental strands only are affected. The possibility is now being examined that breakdown is initiated at the chromosomal origin.

Enzymes concerned in thymine dimer excision and in host specificity mechanisms are not activated by colicin E 2, nor is the ATP-dependent nuclease which is determined by the RecB and RecC genes (Buttin \& Wright, 1968; Barbour \& Clark, 1970). We found no decrease in colicin E2-directed DNA breakdown in a variety of Escherichia coli mutants which are temperature-sensitive for DNA replication. Obinata \& Mizuno ( 1970) have shown that at least in the early stages of E2-induced DNA breakdown, a specific endonuclease (but not endonuclease I) is involved. Further screening among DNA repair and replication mutants may well yield strains which lack one or more of the E 2-specific nucleases. 
We gratefully acknowledge the receipt of a Medical Research Council grant which enabled us to carry out these studies.

\section{ADDENDUM}

After preparation of this paper, Ringrose (Biochimica et biophysica acta, 1970, vol. 213, pp. 320-334) reported that DNA breakdown induced by E 2 proceeds initially via single-strand breaks and that these can be repaired and their further formation halted if the bacteria are treated at an early stage with trypsin. This report further supports the hypothesis proposed here that membrane changes induced by $\mathrm{E} 2$ are reversible and that these changes directly affect the activity of a membrane-bound nuclease.

\section{REFERENCES}

Barbour, S. D. \& ClARK, A. J. (1970). Biochemical and genetic studies of recombination proticiency in Escherichia coli. I. Enzymatic activity associated with $r e c \mathrm{~B}^{+}$and $r e c \mathrm{C}^{+}$genes. Proceedings of the National Academy of Sciences of the United States of America 65, 955-96I.

Boyce, R. P. \& Howard-Flanders, P. (1964). Genetic control of DNA breakdown and repair in E. coli $\mathrm{K} 2 \mathrm{2}$ treated with mitomycin C or ultraviolet light. Zeitschrift für Vererbungslehre 95, 345-350.

ButTIN, G. \& WRIGHT, M. (1968). Enzymatic DNA degradation in E. coli: Its relationship to synthetic processes at the chromosome level. Cold Spring Harbor Symposia on Quantitative Biology 33, 259-269.

Changeux, J. P. \& Thiery, J. (1967). On the mode of action of colicins: A model of regulation at the membrane level. Journal of Theoretical Biology 17, 315-318.

CLARK, A. J. (1967). The beginning of a genetic analysis of recombination proficiency. Journal of Cell Physiology 70, suppl. 1, I65-180.

FANGMAN, W. L. \& NovicK, A. (1968). Characterization of two bacteria mutants with temperaturesensitive synthesis of DNA. Genetics 60, I-I7.

GLOVER, S. W. (1970). Functional analysis of host specificity mutants in Escherichia coli. Genetical Research, Cambridge 15, 237-250.

Gross, J. D. \& Gross, M. (1969). Genetic analysis of an Escherichia coli strain with a mutation affecting DNA polymerase. Nature, London 224, $1166-1168$.

HeRsChman, H. R. \& Helinski, D. R. (1967). Purification and characterization of colicin E2 and colicin E 3. Journal of Biological Chemistry 242, 5360-5368.

HILl, C. \& Holland, I. B. (1967). The genetic basis of colicin E sensitivity in Escherichia coli $\mathrm{K} I 2$. I. Isolation and properties of refractory mutants and the preliminary mapping of their mutations. Journal of Bacteriology 94, 677-686.

HiRota, Y., Ryter, A. \& JACOB, F. (1968). Thermosensitive mutants of $E$. coli affected in the processes of DNA synthesis and cellular division. Cold Spring Harbor Symposia on Quantitative Biology 33, 677-693.

Holland, I. B. (1967). The properties of u.v.-sensitive mutants of Escherichia coli $\mathrm{K} 12$ which are also refractory to colicin E2. Molecular and General Genetics roo, 242-25I.

Holland, I. B. (1968). Properties of Escherichia coli $\mathrm{K} I 2$ mutants which show conditional refractivity to colicin E2. Journal of Molecular Biology 31, 267-275.

Holland, I. B., Threlfall, E. J., Holland, E. M., Darby, V. \& Samson, A. C. R. (1970). Mutants of Escherichia coli with altered surface properties which are refractory to colicin E2, sensitive to ultraviolet light and which can also show recombination deficiency, abortive growth of bacteriophage $\lambda$ and filament formation. Journal of General Microbiology 62, 371-382.

HowARD-Flanders, P. \& Theriot, L. (1966). Mutants of $E$. coli K 12 defective in DNA repair and in genetic recombination. Genetics 53, I $137-1150$.

HubaceK, J. \& Glover, S. W. (1970). Complementation analysis of temperature-sensitive host specificity mutations in Escherichia coli. Journal of Molecular Biology 50, I I I-127.

JacoB, F., Siminovitch, L. \& Wollman, E. (1952). [Sur la biosynthèse d'une colicine et sur son mode d'action. Annales de l'Institut Pasteur, Paris 83, 295-315. 
KonISKY, J. \& NoMURA, M. (1967). Interaction of colicin with bacterial cells. II. Specific alteration of Escherichia coli ribosomes induced by colicin $\mathrm{E}_{3}$ in vivo. Journal of Molecular Biology 26, I8I-195.

Levinthal, F. \& Levinthal, C. cited by LuRIA, S. E. (I964). On the mechanisms of action of colicins. Annales de l'Institut Pasteur, Paris 107, 67-73.

MaEda, A. \& Nomura, M. (I966). Interaction of colicins with bacterial cells. I. Studies with radioactive colicins. Journal of Bacteriology 9r, 685-694.

Meselson, M. \& Yuan, R. (1968). DNA restriction enzyme from Escherichia coli. Nature, London 2I7, IIIO-III4.

NAGEL DE ZWAIG, R. \& LURIA, S. E. (1967). Genetics and physiology of colicin-tolerant mutants of Escherichia coli. Journal of Bacteriology 93, I I $12-1$ I 23.

NAGEL DE Zwaig, R. \& LURIA, S. E. (I969). New class of conditional colicin-tolerant mutants. Journal of Bacteriology $99,78-84$.

NomuRA, M. (1963). Mode of action of colicines. Cold Spring Harbor Symposia on Quantitative Biology 28, 31 5-324.

Nomura, M. (1964). Mechanism of action of colicines. Proceedings of the National Academy of Sciences of the United States of America 52, $1514-1521$.

NomuRA, M. \& MAEDA, A. (1965). Mechanism of action of colicines. Zentralblatt für Bakteriologie, Parasitenkunde, Infektionskrankheiten und Hygiene (Abteilung I Originale). 196, 216-238.

NomURA, M. \& NaKamura, M. (1962). Reversibility of inhibition of nucleic acids and protein synthesis by colicin K. Biochemical and Biophysical Research Communications 7, 306-309.

NomURA, M. \& WitTen, C. (1967). Interaction of colicins with bacterial cells. III. Colicin-tolerant mutations in Escherichia coli. Journal of Bacteriology 94, 1093-I I I .

Obinata, M. \& Mizuno, D. (1970). Mechanism of E2-induced DNA degradation in Escherichia coli. Biochimica et biophysica acta 199, 330-339.

Pritchard, R. H., Barth, P. T. \& Collins, J. (1969). Control of DNA synthesis in bacteria. Symposia of the Society for General Microbiology 21, 263-297.

ReYNolds, B. L. \& ReEves, P. R. (I963). Some observations on the mode of action of colicin F. Biochemical and Biophysical Research Communications II, I40-145.

ReYNolds, B. L. \& ReEves, P. R. (1969). Kinetics of adsorption of colicin CA42-E2 and reversal of its bacteriocidal activity. Journal of Bacteriology 100, 301-309.

Rothfield, L. \& Pearlman-Kothencz, M. (1969). Synthesis and assembly of bacterial membrane components. A lipopolysaccharide-phospholipid-protein complex excreted by living bacteria. Journal of Molecular Biology 44, 477-492.

Samson, A. C. R. \& Holland, I. B. (1970). Envelope protein changes in mutants of Escherichia coli refractory to colicin E2. Febs Letters II, 33-36.

Shannon, R. \& Hedges, A. J. (1967). Kinetics of lethal adsorption of colicin E2 by Escherichia coli. Journal of Bacteriology 93, 1353-I359.

SueokA, N. \& QuinN, W. G. (1968). Membrane attachment of the chromosome replication origin in Bacillus subtilis. Cold Spring Harbor Symposia on Quantitative Biology 33, 695-705.

Van de Putte, P., Van Sluis, C. A., Van Dillewisn, J. \& Rörsch, A. (1965). The location of genes controlling radiation sensitivity in Escherichia coli. Mutation Research 2, 97-I 10.

VAN De Putte, P., Zwenk, H. \& RöRsch, A. (1966). Properties of four mutants of Escherichia coli defective in genetic recombination. Mutation Research 3, 38I-392. 